\title{
ДИНАМІКА СПРАВЛЯННЯ ТА НАДХОДЖЕННЯ ЗЕМЕЛЬНИХ ПЛАТЕЖІВ У ТРАДИЦІЙНОМУ ТА ОРГАНІЧНОМУ СІЛЬСЬКОГОСПОДАРСЬКОМУ ЗЕМЛЕКОРИСТУВАННІ В УКРАЇНІ
}

\author{
Н.Л. Хомюк \\ кандидат економічних наук
}

Східноєвропейський національний університет імені Лесі Українки

(Україна, м. Луцьк, e-mail: nataljabilous@gmail.com)

\begin{abstract}
Здійснено аналіз справляння та надходження земелъних платежів у традииійному та органічному сілъсъкогосподарсъкому землекористуванні в Україні. Виявлено зменшення частки плати за землю у податкових доходах зведеного бюджету України за умови збереження динаміки зростання ббактичних надходжень. Розкрито зміни в структурі плати за землю в напрялі збільшення частки орендної плати у ијій структурі. Здійснено аналіз надходження плати за землю до місиевих бюджетів у розрізі платників податків. Виявлено, шуо надходження извого платежу від юридичних осіб становитъ близъко 90\%, тоді як від gбізичних осіб - близъко 10\%. Проведений аналіз структури надходжень плати за землю в динаміщі за період 2012-2018 років з використанням балансового методу надав змогу виявити вплив кожного елементу плати за землю на загальну суму наджодженъ та динаміку їх зміни за роками. Обгрунтовано значення єдиного податку четвертої групи як податкового регулятора використання зелель сільсъкогосподарсъкого призначення та джерела наповнення місцевих бюджетів. Виявлено, шуо надходження від сплати єдиного податку впродовж 2009-2014 рр. не змінювалися, а у 2015 р. зросли у 17 разів, порівняно з попереднім періодом, шо обумовлено запровадженням шорічної індексаиї бази оподаткування та збілъшенням ставок податку для сілъгосппідприємств. Єәиним легітимним видом користування землями сілъсъкогосподарсъкого призначення визначено оренду. Запропоновано внести зміни до податкового законодавства шодо сплати земельних платежів органічними землекористувачами.
\end{abstract}

Ключові слова: земельний платіж, плата за землю, земелъний податок, орендна плата за землі державної та комунальної власності, орендна плата, єдиний податок, місиевий бюджет, сілъсъкогосподарсъке землекористування, органічне землекористування, юридична особа, фбізична особа.

Постановка проблеми. Площа земель сільськогосподарського призначення в Україні становить близько $71 \%$ площі ї̈ земельного фонду, з якої 47\% використовується на умовах оренди. Плата за користування сільськогосподарськими угіддями є одним з елементів системи економічного регулювання земельних відносин, другим за обсягом джерелом фріскальних надходжень до місцевих бюджетів. Проте цей податковий платіж не має цільового призначення, а тому не використовується на фінансування заходів з охорони земель. Через земельний податок та єдиний податок четвертої групи, що сплачують землекористувачі, реалізуються економічні відносини між власниками земельних ділянок та державою, а за допомогою орендної плати — між власниками землі та землекористувачами.

Окрім того, в Україні є всі передумови для розвитку та поширення органічного сільськогосподарського виробництва, як-от: наявність площ екологічно чистих земель сільськогосподарського призначення з високою родючістю, сприятливі кліматичні умови, внесення міне- ральних добрив є незначними тощо. На сьогодні статус органічних та земель перехідним періодом в Україні мають 381173 га сільськогосподарських угідь, тобто частка органічних земель від загальної площі сільськогосподарських земель становить близько 0,9\%.

Аналіз останніх досліджень і публікації. Дослідженням проблем сільськогосподарського землекористування та його платності приділяли увагу вчені П.М. Боровик, В.А. Голян, В.С. Данкевич, Ю.О. Лупенко, А.Г. Мартин, B.I. Павлов, П.Т. Саблук, М.Г. Ступень, А.Я. Сохнич, А.М. Третяк, Л.Д. Тулуш, М.А. Хвесик, В.В. Хохуляк та ін. Поряд із тим аналітичні аспекти нарахування та справляння земельних платежів у традиційному та органічному сільськогосподарському землекористуванні залишаються поза увагою.

Виділення невирішених раніше частин загальної проблеми. Незважаючи на істотні досягнення у дослідженні сільськогосподарського землекористування, низка питань щодо сплати земельних платежів залишаються недостатньо опрацьованими. 3 огляду на це, особ- 
ливо актуальним є аналіз процесу справляння та надходження податкових та неподаткових земельних платежів у традиційному сільськогосподарському землекористуванні, а також розробка пропозицій щодо оподаткування органічних землекористувачів.

Метою дослідження є визначення та аналіз динаміки справляння та надходження земельних платежів у традиційному та органічному сільськогосподарському землекористуванні в Україні.

Матеріали та методи. Теоретико-методологічною основою дослідження є методи та підходи класичної економічної теорії, як-от системний, аналізу та синтезу, аналітичний та економіко-статистичний. Інформаційною базою дослідження слугували вітчизняні та міжнародні нормативно-правові акти у сорері платності сільськогосподарського землекористування, матеріали і звіти Державної казначейської служби України Державної служби України з питань геодезії, картографрії та кадастру, наукові праці вітчизняних авторів, а також інформація з мережі Інтернет, матеріали власних досліджень, інші тематичні літературні джерела.

Викладення основного матеріалу. У зведеному бюджеті України станом на кінець 2018 р. плата за землю, як складова податку на майно, становила лише $3 \%$ від загальної суми податкових надходжень, а у місцевих бюджетах - $12 \%$. Надходження плати за землю у 2018 р. становили 27,3 млрд грн, що на 0,9 та 14,7 млрд грн більше, ніж у 2017 та 2012 рр. відповідно (рис. 1). Частка плати за землю у податкових доходах зведеного бюджету зменшу- ється за умови збереження динаміки зростання фрактичних надходжень. Винятком є 2014 р., коли спостерігалось зменшення податкових надходжень [1]. У 2018 р. ця частка зменшилась порівняно з 2012 р. на $0,6 \%$ та становила $2,9 \%$.

На рис. 2 відображено надходження плати за землю впродовж 1992-2018 рр.

Слід зауважити, що сума надходжень від земельного податку з юридичних осіб зросла від 3211,0 млн грн у 2012 р. до 8241,2 млн грн у 2018 р.; із земельного податку фрізичних осіб - від 403,4 млн грн у 2012 р. до 1629,4 млн грн у 2018 р. Аналогічно збільшилась сума надходжень від орендної плати з юридичних осіб від 7816,9 млн грн у 2012 р. до 15288,1 млн грн у 2018 р. та 3 орендної плати фізичних осіб - від 1150,4 млн грн у 2012 р. до 2162,4 млн грн у 2018 р.

Під час аналізу спостерігається тенденція зростання надходжень плати за землю впродовж аналізованого періоду. Проте у 2014 р. унаслідок політичної і економічної ситуації в Україні сума надходжень порівняно з 2013 р. зменшилась на 719,0 млн грн, з них орендна плата від юридичних осіб — на 412,6 млн грн (табл. 2). У 2015 р. сума надходжень порівняно 32014 р. збільшилась на 2747,6 млн грн, 3 них орендна плата від юридичних осіб - на 1594,2 млн грн. У 2018 р. сума надходжень порівняно з 2017 р. збільшилась на 936,6 млн грн, з них орендна плата від юридичних осіб — на 586,5 млн грн. Упродовж аналізованого періоду сума надходжень плати за землю збільшилась на 14739,4 млн грн.

Зростання надходжень плати за землю до місцевих бюджетів у 2015-2018 рр. обумовлено змінами законодавства. Законом України (ЗУ)

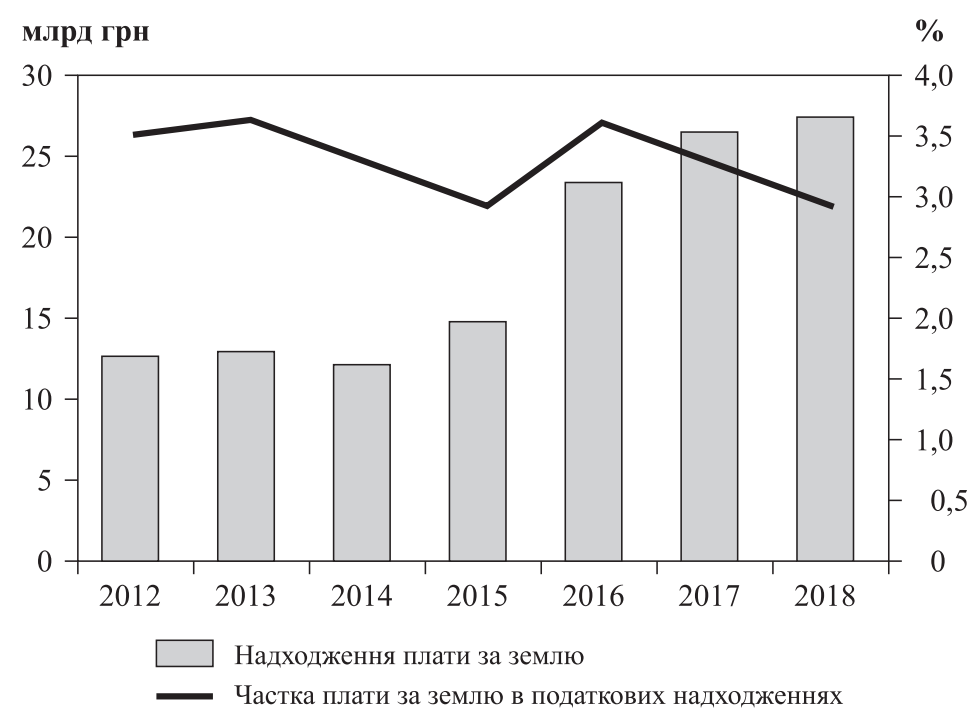

Рис. 1. Диналіка надходженъ плати за землю до зведеного бюджету України у 2012-2018 рр. Джерело: побудовано на основі даних Державної казначейської служби України [2]. 


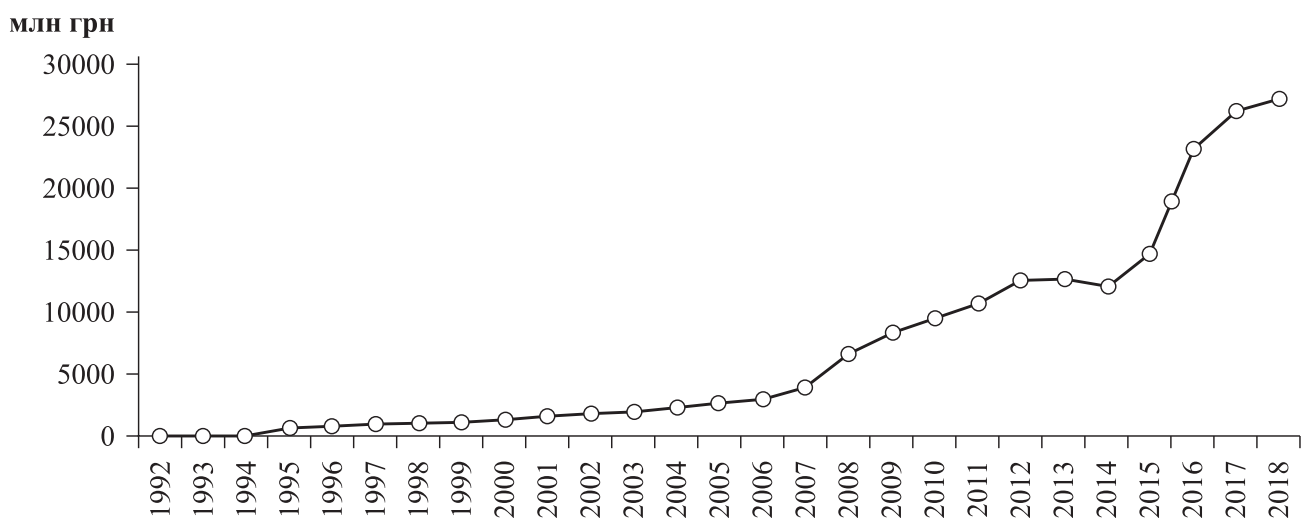

Рис. 2. Надходження плати за землю у 1992-2018 рр.

Джерело: побудовано на основі даних Державної казначейської служби України [2] та Інформаційного ресурсу [3].

Таблиияя 1

Надходження плати за землю у 2012-2018 рр.

\begin{tabular}{|l|c|c|c|c|c|c|c|}
\hline \multicolumn{1}{|c|}{ Показник, млн грн } & $\mathbf{2 0 1 2}$ & $\mathbf{2 0 1 3}$ & $\mathbf{2 0 1 4}$ & $\mathbf{2 0 1 5}$ & $\mathbf{2 0 1 6}$ & $\mathbf{2 0 1 7}$ & $\mathbf{2 0 1 8}$ \\
\hline \hline Плата за землю & 12581,7 & 12802,9 & 12083,9 & 14831,5 & 23323,6 & 26384,5 & 27321,1 \\
\hline $\begin{array}{l}\text { Земельний податок } \\
\text { з юридичних осіб }\end{array}$ & 3211,0 & 2950 & 2776,4 & 3558,8 & 7061 & 8262,3 & 8241,2 \\
\hline $\begin{array}{l}\text { Орендна плата з юридич- } \\
\text { них осіб }\end{array}$ & 7816,9 & 8232,3 & 7819,7 & 9413,9 & 13351,4 & 14701,6 & 15288,1 \\
\hline $\begin{array}{l}\text { Земельний податок } \\
\text { з фрізичних осіб }\end{array}$ & 403,4 & 416,1 & 384,9 & 501,1 & 1032,3 & 1387,4 & 1629,4 \\
\hline $\begin{array}{l}\text { Орендна плата з фрізич- } \\
\text { них осіб }\end{array}$ & 1150,4 & 1204,5 & 1102,9 & 1357,7 & 1878,9 & 2033,2 & 2162,4 \\
\hline
\end{tabular}

Джерело: узагальнено на основі даних Державної казначейської служби України [2].

Таблиия 2

Абсолютні відхилення надходжень плати за землю у 2012-2018 рр.

\begin{tabular}{|l|c|c|c|c|c|c|c|}
\hline \multirow{2}{*}{\multicolumn{1}{|c|}{ Показник, млн грн }} & \multicolumn{7}{|c|}{ Абсолютні відхилення, млн грн } \\
\cline { 2 - 8 } & $\begin{array}{c}\mathbf{2 0 1 8 -} \\
\mathbf{2 0 1 7}\end{array}$ & $\begin{array}{c}\mathbf{2 0 1 7 -} \\
\mathbf{2 0 1 6}\end{array}$ & $\begin{array}{c}\mathbf{2 0 1 6 -} \\
\mathbf{2 0 1 5}\end{array}$ & $\begin{array}{c}\mathbf{2 0 1 5 -} \\
\mathbf{2 0 1 4}\end{array}$ & $\begin{array}{c}\mathbf{2 0 1 4 -} \\
\mathbf{2 0 1 3}\end{array}$ & $\begin{array}{c}\mathbf{2 0 1 3 -} \\
\mathbf{2 0 1 2}\end{array}$ & $\begin{array}{c}2018- \\
2012\end{array}$ \\
\hline \hline Плата за землю & 936,6 & 3060,9 & 8492,1 & 2747,6 & -719 & 221,2 & 14739,4 \\
\hline $\begin{array}{l}\text { Земельний податок з юри- } \\
\text { дичних осіб }\end{array}$ & $-21,1$ & 1201,3 & 3502,2 & 782,4 & $-173,6$ & -261 & 5030,2 \\
\hline $\begin{array}{l}\text { Орендна плата з юридичних } \\
\text { осіб }\end{array}$ & 586,5 & 1350,2 & 3937,5 & 1594,2 & $-412,6$ & 415,4 & 7471,2 \\
\hline $\begin{array}{l}\text { Земельний податок з фрізич- } \\
\text { них осіб }\end{array}$ & 242 & 355,1 & 531,2 & 116,2 & $-31,2$ & 12,7 & 1226 \\
\hline $\begin{array}{l}\text { Орендна плата з фрізичних } \\
\text { осіб }\end{array}$ & 129,2 & 154,3 & 521,2 & 254,8 & $-101,6$ & 54,1 & 1012 \\
\hline
\end{tabular}

Джерело: розраховано на основі даних Державної казначейської служби України [2].

«Про внесення змін до Податкового кодексу України та деяких законодавчих актів України щодо податкової рефрорми» від 28.12.2014 р. [4] плату за землю переведено із загальнодержавного податку до місцевого у складі податку на майно, що налічує у своєму складі і податок на нерухоме майно (окремо від земельної ділянки) та транспортний податок. Тому з 2015 р. Податковим кодексом України встановлено лише граничні ставки земельного податку, а 
конкретний розмір ставок визначають органи місцевого самоврядування. Зростання надходжень орендної плати до місцевих бюджетів обумовлено введенням у дію ЗУ «Про запобігання фінансової катастрофи та створення умов для економічного зростання в Україні» від 27.03.2014 р. [5] та ЗУ «Про внесення змін до Податкового кодексу України щодо покращення інвестиційного клімату в Україні» від 21.12.2016 р. [6], згідно з якими річна сума орендної плати за землі державної та комунальної власності сільськогосподарського призначення не може бути меншою ніж $0,3 \%$ та не більшою ніж $1 \%$ від їх нормативної грошової оцінки, тобто не менше за розмір земельного податку.

Відповідно, структура плати за землю за 2012-2018 рр. також зазнала певних змін (рис. 3). Якщо у 2012 р. земельний податок (з юридичних та фрізичних осіб) становив $28,7 \%$ від загального обсягу надходжень плати за землю, то у 2018 р. цей показник зріс до $36,1 \%$. Надходження від орендної плати у 2018 р. становили 63,9\% загального обсягу надходжень плати за землю, а у 2012 р. - 71,3\%.

Збільшення частки земельного податку у структурі плати за землю обумовлено змінами у податковому законодавстві, що здійснюються у рамках рефрорми децентралізації, яка визначає напрями, механізми і строки фрормування ефективного місцевого самоврядування та територіальної організації влади для створення і підтримки повноцінного життєвого середовища для громадян, надання високоякісних та доступних публічних послуг, становлення інститутів прямого народовладдя, задоволення інтересів громадян у всіх сорерах життєдіяльності на відповідній території, узгодження інтересів держави та територіальних громад [7]. Ця рефрорма передбачає створення спроможних громад, які за допомогою власних ресурсів зможуть розв' язувати проблеми сільських та місь- ких територій [8]. Процес децентралізації дає можливість органам місцевого самоврядування самостійно приймати рішення щодо фрінансових питань, у т.ч. стосовно наповнення місцевих бюджетів, завдяки встановленню ставок місцевих податків, як-от податок на майно та єдиний податок. Тому згадана реформа сприяє підвищенню ефективності використання бюджетних коштів на усіх рівнях управління та є дієвим чинником стабілізації соціально-економічної ситуації в Україні.

На думку В. Голяна [9], особливою складністю відзначаються процеси наповнення бюджетів сільських територіальних громад. Це обумовлено тим, що за багато років реляцій представників влади про “унікальну» модель редрормування аграрного сектора України як базової ланки сільського розвитку так і не було реально розширено податкову базу наповнення сільських бюджетів, хоча потенційно для цього було і є безліч можливостей.

31 лютого 2018 р. Держгеокадастром розпочато процес передачі земельних ділянок сільськогосподарського призначення державної власності у комунальну власність об'єднаних територіальних громад. Наприкінці 2018 р. 646 об'єднаних територіальних громад отримали 1450,8 тис. га земель сільськогосподарського призначення, або 97,6\% ОТГ, які отримали земельні ділянки, від запланованих, згідно з планом-графіком, затвердженим Кабінетом Міністрів України.

Найбільшу суму надходжень плати за землю до зведеного бюджету у 2018 р. внесли юридичні особи - 23529,3 млн грн, або 86,1\% від загального обсягу надходжень (рис. 4). Надходження від фізичних осіб становлять лише 13,9\% від загального обсягу надходжень плати за землю.

Відповідно до ст. 271.1 Податкового кодексу України базою оподаткування земельним по-

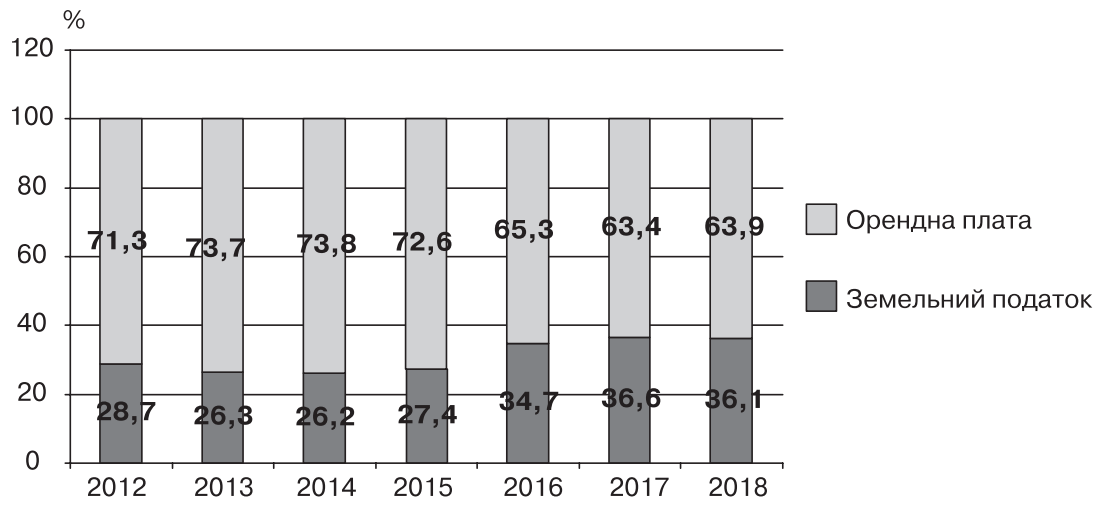

Рис. 3. Співвідношення земельного податку та орендної плати у 2012-2018 рр. Джерело: побудовано на основі даних Державної казначейської служби України [2]. 


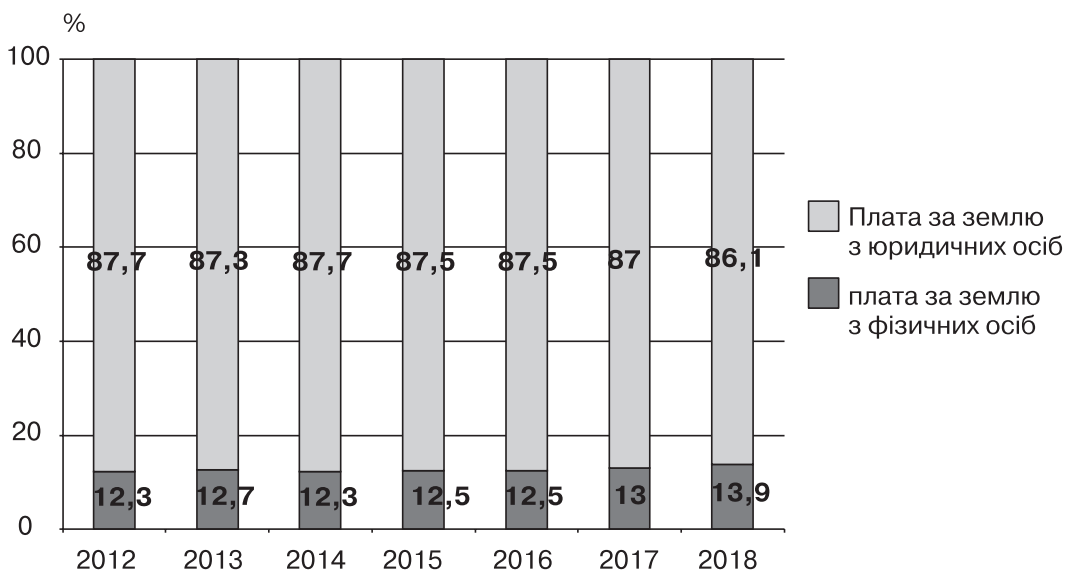

Рис. 4. Співвідношення плати за землю з юридичних та боізичних осіб у 2012-2018 рр.

Джерело: побудовано на основі даних Державної казначейської служби України [2].

датком в Україні є нормативна грошова оцінка земельних ділянок з урахуванням коефіцієнта індексації та площа земельних ділянок, нормативну грошову оцінку яких не проведено [10]. Тому зміни у надходженнях плати за землю обумовлено індексацією бази оподаткування земельних ділянок (нормативної грошової оцінки ріллі). Але підвищення нормативної грошової оцінки ріллі не дає змоги повною мірою забезпечити об'єктивність та достовірність показників нормативної грошової оцінки земель сільськогосподарського призначення щодо сучасних умов господарювання. Адже за основу розрахунку нормативної грошової оцінки земель сільськогосподарського призначення взято рентний дохід, який створюється у процесі виробництва зернових культур без кукурудзи і визначається за даними економічної оцінки земель, проведеної в 1988 р. Тому під час здійснення оцінки земель з метою оподаткування необхідно враховувати сучасний екологічний стан грунтів, що визначається за результатами проведення екологічного аудиту.

Дослідження стану грунтів свідчить про безупинне зниження ї родючості і підвищення темпів деградації. Одним із способів відновлення природного потенціалу земель сільськогосподарського призначення є застосування органічного виробництва. Хоча витрати на таку діяльність є значно більшими, але і органічна продукція на світовому ринку цінується набагато вище, оскільки вирощена без застосування мінеральних добрив.

Одним з методичних підходів до фрінансової державної підтримки органічних операторів є пільгове оподаткування, тобто надання пільг за сплати податку на прибуток та податку на нерухомість або звільнення від їх сплати на певний період. Однією з переваг надання податкових пільг є те, що держава не витрачає реальних коштів на підтримку органічних операторів. Адже уряду іноді простіше затвердити надання податкових пільг для органічних операторів, ніж закріпити в бюджеті витрати на розвиток органічного сільського господарства. Хоча і держава через такий підхід до надання державної підтримки недоотримує частину податкових надходжень у бюджет.

Єдиним легітимним видом користування землями сільськогосподарського призначення є оренда. Оренда земель сільськогосподарського призначення - платне користування земельною ділянкою сільськогосподарського призначення чи земельною часткою (паєм) на умовах договору, складеного відповідно до чинного законодавства, зі збереженням її цільового призначення.

За даними Держгеокадастру [11] із 6,8 млн громадян, які одержали сертифікати на право на земельну частку (пай) або державний акт на право власності на земельну ділянку, 4,8 млн селян реалізують своє право через орендні відносини. У 2015 р. було зареєстровано 4781,9 тис. укладених догорів оренди земельної частки (паю), з яких: $33,1 \%$ - з господарствами, із земель яких виділено земельний пай, або з їх правонаступниками; 14,7 - 3 фрермерськими господарствами; 52,2\% - з іншими суб'єктами господарювання. Близько 17,2 млн га земельних часток (паїв) було передано в оренду.

Договори оренди земельних ділянок та земельних часток (паїв) можуть укладатися на різні терміни. Слід наголосити, що у 2015 р. найбільше укладено договорів оренди на 6-10 років (табл. 3). Такі терміни надають змогу орендарям здійснювати капіталовкладення у поліпшення земель з метою подальшого отримання прибутків. До 2012 р. спостерігалася тенденція до укладання договорів терміном на $4-5$ років. 
Укладання договорів оренди в Україні за строком їх дії

\begin{tabular}{|c|c|c|c|c|c|c|}
\hline \multirow{2}{*}{ Строк дії договору } & \multicolumn{7}{|c|}{ На початок року, \% } \\
\cline { 2 - 7 } & $\mathbf{2 0 0 1}$ & $\mathbf{2 0 0 5}$ & $\mathbf{2 0 1 0}$ & $\mathbf{2 0 1 2}$ & $\mathbf{2 0 1 4}$ & $\mathbf{2 0 1 6}$ \\
\hline \hline $1-3$ роки & 45,7 & 26,2 & 10,0 & 6,5 & 4,0 & 2,7 \\
\hline $4-5$ років & 41,2 & 61,4 & 49,0 & 42,9 & 37,7 & 33,8 \\
\hline $6-10$ років & 11,3 & 10,2 & 30,6 & 38,1 & 43,7 & 48,0 \\
\hline понад 10 років & 1,8 & 2,2 & 10,4 & 12,5 & 14,6 & 15,5 \\
\hline
\end{tabular}

Джерело: складено на основі даних Держгеокадастру [11].

У багатьох країнах встановлено мінімальні терміни оренди земель: у Данії - 30 років, Японії - 20, Італії - 15, Франції - 12, у Нідерландах -6 років. Світовий досвід також свідчить, що в країнах з розвиненою економікою поширеною є довгострокова оренда землі (понад 10 років). Натомість в Україні упродовж тривалого періоду була поширена короткострокова оренда (до 5 років). Але короткострокова оренда не сприяє раціональному землекористуванню та збереженню земель єдиним масивом. Орендарі не зацікавлені вносити мінеральні та органічні добрива, вживати різних меліоративних заходів і витрачати власні кошти, адже віддача від ї проведених настає після закінчення дії договору оренди [12]. Але існує й низка переваг від земельних орендних відносин, як-от: виключення спекуляції із землею, контроль держави за використання земель, поповнення місцевих бюджетів завдяки орендній платі за землі державної та комунальної власності.

3 1.01.2019 р. термін користування земельною ділянкою державної, комунальної та приватної власності для сільськогосподарських потреб (емфітевзис) не може перевищувати 50 років.
Розмір оренди встановлюється в договорі оренди, проте згідно із законодавством не може бути нижчим $3 \%$ від нормативної грошової оцінки земель, яка щорічно індексується. У 2013 р. було укладено договорів: з відсотком орендної плати до 1,5\% - 122,6 тис.; $1,5-3-848$ тис.; понад $3 \%-3796,9$ тис. Порівняно з попередніми роками спостерігається тенденція до зростання кількості договорів з відсотком орендної плати від трьох і більше. Загальна сума виплат за оренду земельних часток (паїв) у 2015 р. становила 13832 млн грн (табл. 4).

Слід відзначити позитивні зміни у структурі виплат за орендовану земельну частку. Якщо на початок 2010 р. натуральна форма сплати становила $71,6 \%$, а грошова лише 24,6 , то на початок 2016 р. грошова форма виплат зросла до 43,6, а натуральна - зменшилась до 53,6\%. Отже, можна зробити висновок, що зростає виплата орендної плати у грошовій формі і зменшується - у натуральній та відробітковій.

За даними Держгеокадастру середня вартість оренди земель в Україні на початок 2018 р. становила 1369 грн/га на 1 рік. Найвищі ставки оренди за 1 га земель сільськогосподарського

таблиия 4

Плата за оренду земельних паӥв (часток) в Україні

\begin{tabular}{|l|c|c|c|c|c|c|c|}
\hline \multirow{2}{*}{ Показник } & \multicolumn{7}{c|}{ На початок року } \\
\cline { 2 - 9 } & $\mathbf{2 0 0 1}$ & $\mathbf{2 0 0 8}$ & $\mathbf{2 0 1 0}$ & $\mathbf{2 0 1 2}$ & $\mathbf{2 0 1 4}$ & $\mathbf{2 0 1 6}$ & $\mathbf{2 0 1 8}$ \\
\hline \hline $\begin{array}{l}\text { Загальна сума виплат згідно з укладе- } \\
\text { ними договорами оренди, млн грн }\end{array}$ & 1589 & 2438 & 4547 & 6052 & 10705 & 13832 & \\
\hline $\begin{array}{l}\text { з них за форммами орендної плати, \%: } \\
\text { грошова }\end{array}$ & 14,0 & 18,9 & 24,6 & 31,7 & 41,7 & 43,6 & \\
\hline натуральна & 77,4 & 76,5 & 71,6 & 65,2 & 55,1 & 53,6 & \\
\hline відробіткова & 8,6 & 4,6 & 3,7 & 3,1 & 3,2 & 2,8 & \\
\hline Плата за 1 га/рік, грн & 140 & 140 & 260,2 & 348,5 & 616,5 & 832,0 & 1369 \\
\hline
\end{tabular}

Джерело: складено на основі даних Держгеокадастру [11]. 


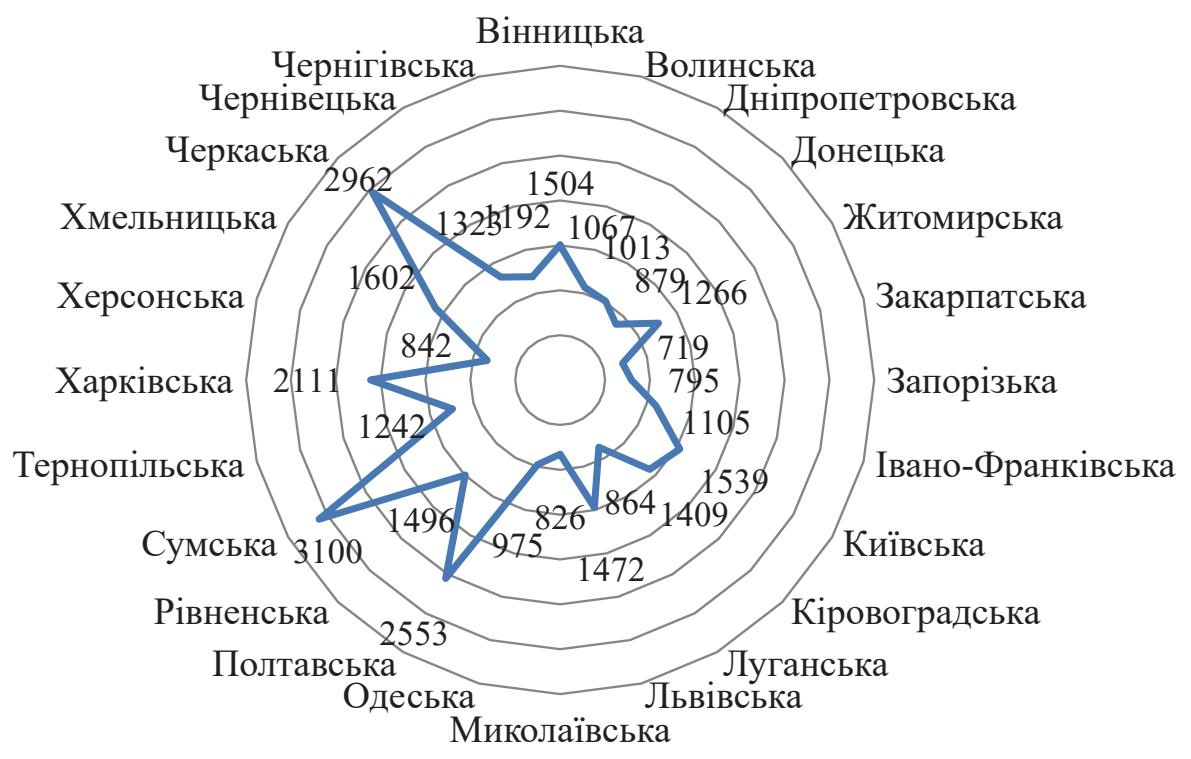

Рис. 5. Середній розмір за оренду земель сілъсъкогосподарсъкого призначення у розрізі регіонів у 2017 р., грн/га

Джерело: побудовано на основі даних Держгеокадастру [13].

призначення (рис. 5) зафріксовано в Черкаській (2962 грн/га), Полтавській (2553) та Харківській (2111 грн/га) областях. Найдешевше можна орендувати землі на Закарпатті - середній орендний платіж у цьому регіоні становить 719 грн/га. Загалом, ставки оренди в Україні відрізняються залежно від регіону в 4,1 раза, або на 2 тис. грн за кожен гектар.

Аналіз засвідчив, що зростанню надходжень земельного податку та орендної плати за земельні ділянки державної та комунальної власності посприяло те, що були вносені зміни до ставок оподаткування, а також те, що для визначення бази оподаткування вказаним податком використовується нормативна грошова оцінка земельних ділянок з урахуванням коефіцієнта індексації. Проте місцеві бюджети недоотримують значні суми надходжень через введення пільгового оподаткування. Так, O.I. Дем'янчук [14] зауважує, що зростання надходжень від плати за землю стримується ставками орендної плати, розмір яких не відповідає ринковим умовам. Тому неврегульованість ситуації із ринком земель сільськогосподарського призначення не дає змогу цьому податку бути фрінансовою основою місцевих бюджетів.

Аналіз структури надходжень плати за землю в динаміці за період 2012-2018 рр. здійснено з використанням балансового методу. Розрахунок сукупності елементів плати за землю здійснено за фрормулою:

$$
\begin{gathered}
\text { Плата за землю }=3 \Pi_{\text {юо }}+\mathrm{O} \Pi_{\text {юо }}+ \\
+3 \Pi_{\text {фо }}+0 \Pi_{\text {фо }},
\end{gathered}
$$

де $3 \Pi_{\text {юо }}$ - земельний податок з юридичних осіб; ОП юо - орендна плата з юридичних осіб; $3 \Pi_{\text {фо }}$ - земельний податок з фізичних осіб; ОП

Результати зведених розрахунків наведено у таблиці 5.

За період 2012-2018 рр. розмір надходжень плати за землю до зведеного бюджету України поступово зростав, хоча у 2014 р. спостерігалося їх зменшення. Так, за 2013 р. плата за землю зросла на 221,2 млн грн, за 2015 р. на 2747,6 , за 2016 р. — на 8492,1 , за 2017 р. на 3060,9 , за 2018 р. — на 936,6 , а за 2014 р. зменшилась на 719 млн грн. Загалом, це сприяло зростанню розміру досліджуваного показника на 14739,4 млн грн $(27321,1-812581,7$ або $221,2-719,0+2747,6+8492,1+3060,9+$ $936,6) .3$ іншого боку, плата за землю зросла завдяки зростанню надходжень від орендної плати з юридичних осіб, земельного податку 3 фрізичних осіб, орендної плати з фрізичних осіб та земельного податку з юридичних осіб - на $7471,2,1226,1012$, та на 5030,2 млн грн (7471,2 + $1226+1012+5030,2=14739,4)$ відповідно. Отже, за результатами аналізу динаміки зміни елементів плати за землю досліджено, якою мірою впливав на зміну загального розміру надходжень кожен елемент зокрема.

Так, зменшення надходжень плати за землю відбулося у 2014 р. (табл. 5, рис. 6). 
таблиия 5

Показники для проведення факторного аналізу елементів плати за землю за 2012-2018 рр.

\begin{tabular}{|c|c|c|c|c|c|c|c|}
\hline \multirow{2}{*}{$\begin{array}{c}\text { Елементи плати за землю, } \\
\text { млн грн }\end{array}$} & \multicolumn{7}{|c|}{ Абсолютні відхилення } \\
\hline & $\begin{array}{l}2013- \\
2012\end{array}$ & $\begin{array}{c}2014- \\
2013\end{array}$ & $\begin{array}{l}2015- \\
2014\end{array}$ & $\begin{array}{c}2016- \\
015\end{array}$ & $\begin{array}{c}2017- \\
2016\end{array}$ & $\begin{array}{c}2018- \\
2017\end{array}$ & $\begin{array}{c}2018- \\
2012\end{array}$ \\
\hline $\begin{array}{l}\text { Земельний податок з юри- } \\
\text { дичних осіб }\end{array}$ & -261 & $-173,6$ & 782,4 & 3502,2 & 1201,3 & $-21,1$ & 5030,2 \\
\hline $\begin{array}{l}\text { Орендна плата з юридич- } \\
\text { них осіб }\end{array}$ & 415,4 & $-412,6$ & 1594,2 & 3937,5 & 1350,2 & 586,5 & 7471,2 \\
\hline $\begin{array}{l}\text { Земельний податок з фрі- } \\
\text { зичних осіб }\end{array}$ & 12,7 & $-31,2$ & 116,2 & 531,2 & 355,1 & 242 & 1226 \\
\hline $\begin{array}{l}\text { Орендна плата з фрізичних } \\
\text { осіб }\end{array}$ & 54,1 & $-101,6$ & 254,8 & 521,2 & 154,3 & 129,2 & 1012 \\
\hline Плата за землю & 221,2 & -719 & 2747,6 & 8492,1 & 3060,9 & 936,6 & 14739,4 \\
\hline
\end{tabular}

Джерело: сформовано на основі даних Державної казначейської служби України [2].

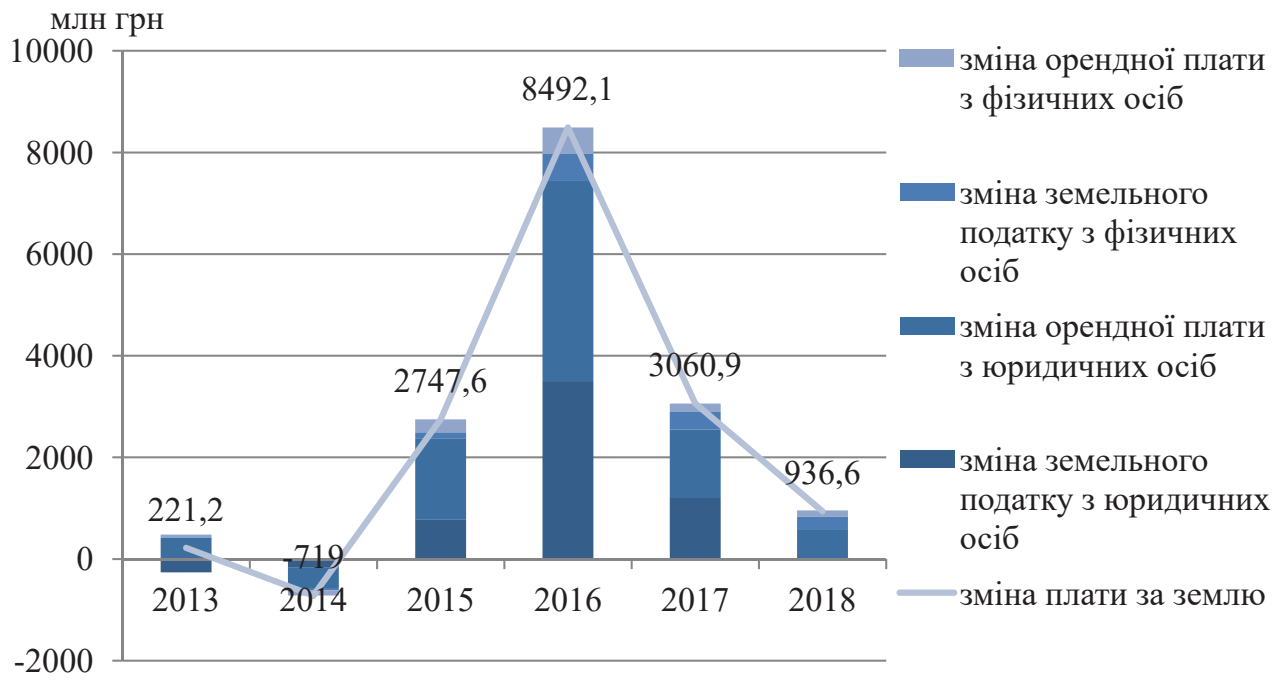

Рис. 6. Приріст надходженъ плати за землю в Україні у розрізі ї складових, 2013-2018 рр. Джерело: побудовано та розраховано на основі даних Державної казначейської служби України [2].

Сукупність елементів податку знизилась на 719 млн грн, що було результатом зменшення земельного податку з юридичних осіб - на 173,6 млн грн, орендної плати з юридичних осіб - на 412,6, земельного податку з фізичних осіб - на 31,2 та орендної плати з орізичних осіб - на 101,6 млн грн. Найбільше зростання плати за землю відбулося у 2016 р. Загальне зростання на 8492,1 млн грн є наслідком впливу зміни в позитивному напрямі всіх елементів плати за землю. Найвагоміший вплив на зміну надходжень плати за землю за 2016 р. мало зростання величини орендної плати з юридичних осіб на 3937,5 млн грн та величини земельного податку з юридичних осіб на 3502,2 млн грн.

Загалом, за період з 2012 до 2018 рр. зросли всі елементи плати за землю. Проте у 2014 р. спостерігається скорочення всіх складових плати за землю внаслідок політичних та економічних проблем у країні. Найменші зміни спостерігалися у розрізі орендної плати з фрізичних осіб, що за аналізований період зросла на 1012 млн грн. Найбільші зміни відбулися з показником «орендна плата 3 юридичних осіб», загальне зростання якого становило 7471,2 млн грн.

Слід зауважити, що загалом спостерігається динаміка зростання надходжень плати за землю (рис. 7). За 2018 р. до місцевих бюджетів поступило 27321,1 млн грн, що на 936,6 млн грн більше, ніж у 2017 р. Унаслідок змін у податковому законодавстві, а саме - 3 переведенням плати за землю у місцевий податковий платіж та з удосконаленням нормативної грошової оцінки земель - спостерігається зростання рівня збо- 


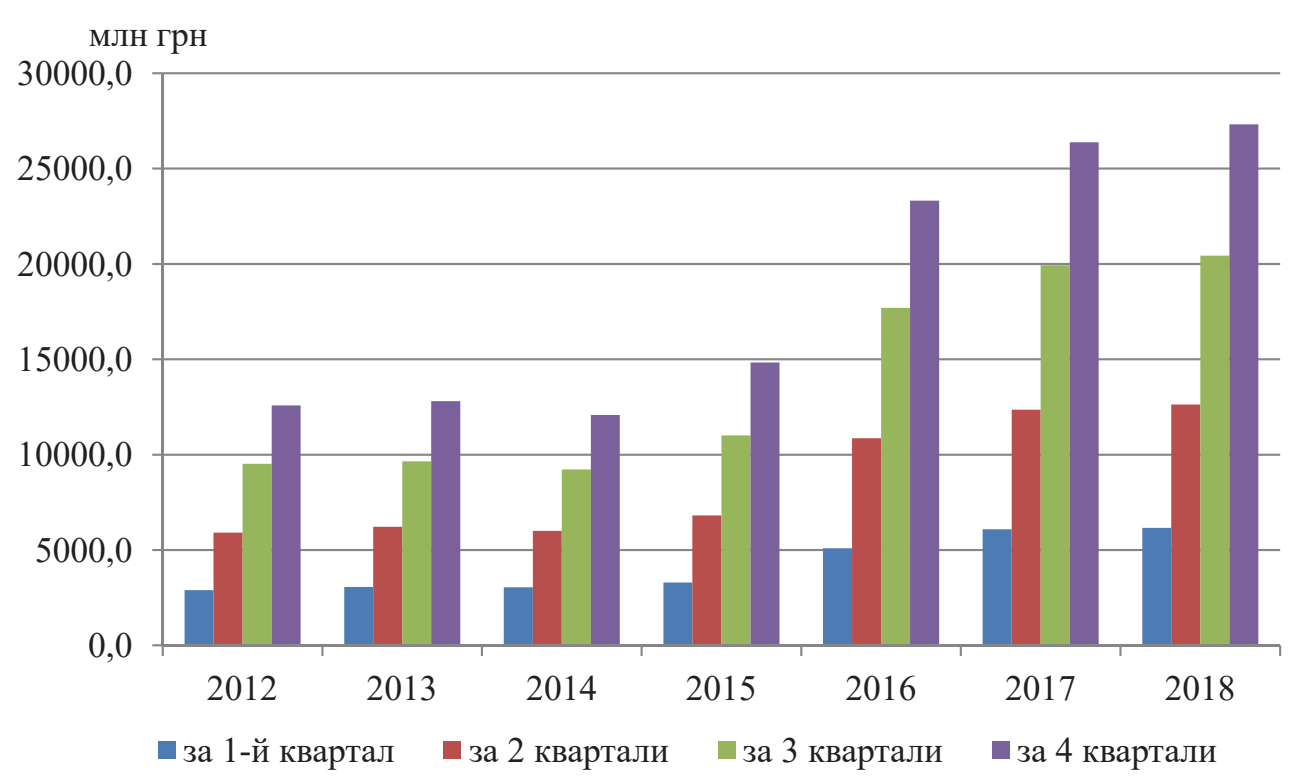

Рис. 7. Динаміка надходженъ плати за землю до місиевих бюджетів, 2012-2018 рр. Джерело: побудовано на основі даних Державної казначейської служби [2].

ру земельного податку до місцевих бюджетів. Ці заходи мають важливе значення, оскільки в державі діє реформа децентралізації.

Слід наголосити, що у деяких країнах (Швеції, Великобританії, Австралії, Голландіï) землі, які належать сільськогосподарським підприємствам або приватним особам, повністю звільнено від оподаткування [15], хоча спеціалісти вважають, що оподаткування сільськогосподарських угідь сприяє ефективнішому їх використанню. Зокрема, у США та Канаді використовується знижена ставка оподаткування.

У Чехії встановлений неоподаткований мінімум площі (до 10 га) сільськогосподарських земель та застосовуються різні ставки оподаткування $(0,25-0,75 \%$ від вартості землі). Для розрахунку податку на землю в Чехії усі земельні угіддя класифрікували на 44 податкові групи: за кращі землі податок становить 930 крон/га, а за менш родючі - 10 крон/га. Така різниця в розмірах податку дає змогу земельним ділянкам з менш якісним грунтовим покривом бути задіяними у процесі сільськогосподарського виробництва. Орендарями таких площ стають ті землекористувачі, які у змозі сплачувати високі податки [16].

В Угорщині також під час нарахування податку на землю орні землі поділяють на 12 класів, багаторічні насадження - на 11, а сіножаті та пасовища - на 8 класів. Ставки земельного податку визначаються для кожного класу окремо, а якщо вартість оцінених сільськогосподарських угідь є занадто низькою, цей податок не стягується.
Прикладом застосування диференційованих ставок до оподаткування земель в Україні є єдиний податок четвертої групи, згідно з якими їх рівень залежить від виду сільськогосподарських угідь (ріллі, сіножатей, пасовищ та багаторічних насаджень) та місця розташування земельної ділянки (у гірських чи рівнинних зонах, закритому грунті тощо) [1, с. 135-136]. Вітчизняні сільськогосподарські товаровиробники мають можливість обирати вид оподаткування, зокрема спеціальний, або залишатися на загальній основі.

Слід зауважити, що спеціального податкового регулювання сільськогосподарського землекористування наразі ще не напрацьовано. Погоджуємося з думкою А. Крисака, що податковим регулятором використання земель сільськогосподарського призначення є фріксований сільськогосподарський податок (нині - єдиний податок четвертої групи), який є синтетичним фріскальним інструментом, адже налічує, крім плати за землю, низку фінансових важелів, які опосередковано стосуються масштабів залучення земельних ресурсів у господарський обіг, тобто результатів господарської діяльності сільгоспвиробника $[17$, с. 8-9].

В Україні надходження фіксованого сільськогосподарського податку до зведеного бюджету впродовж 2012-2014 рр. не змінювалися і становили близько 0,1 млрд грн. Сума надходжень у 2018 р. становила 5272,2 млн грн, що на 5141,2 млн грн більше, ніж у 2012 р. (рис. 8). За 2018 р. до місцевих бюджетів надійшло 5272,2 млн грн від сплати єдиного податку сіль- 


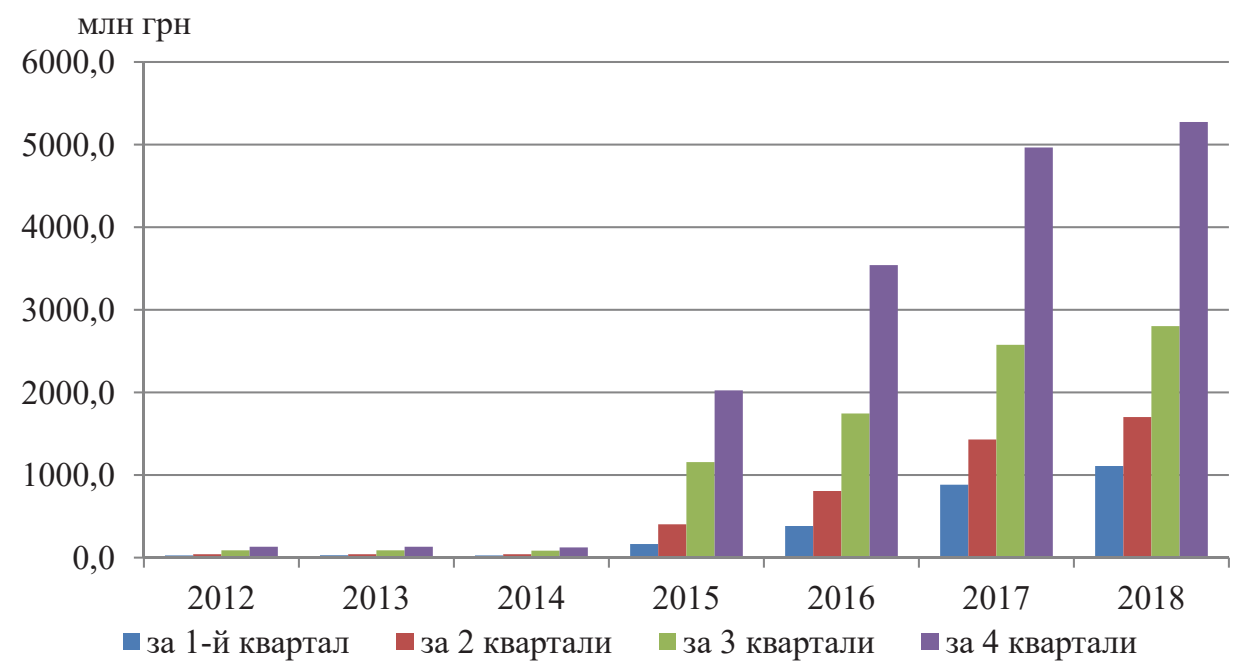

Рис. 8. Динаміка надходжень єдиного податку четвертої групи (раніше ФСП) до місиевих бюджетів, 2012-2018 рр.

Джерело: побудовано на основі даних Державної казначейської служби України [2].

ськогосподарських товаровиробників, що на 307 млн грн більше, ніж у 2017 р.

Різке збільшення надходжень пояснюється тим, що для розрахунку бази оподаткування вказаним податком до 2015 р. використовувалася нормативна грошова оцінка 1 га сільськогосподарських угідь без урахування коефіцієнта індексації. Зростання єдиного податку у 2015 р. у 17 разів, порівняно з попереднім періодом пояснюється запровадженням щорічної індексації бази оподаткування. Крім того, з 1.01.2015 p. ставки спеціального режиму прямого оподаткування для сільгосппідприємств збільшено втричі. Відповідно, якщо у 2014 р. середній розмір ФСП з 1 га сільгоспугідь становив менш ніж 6 грн/га, то у 2015 р. обов'язковий платіж перевищував 115 грн/га. Такі новації дають змогу скерувати єдиний податок на істотне джерело наповнення місцевих бюджетів.

Отже, зростання надходжень єдиного податку впродовж 2015-2018рр. обумовлено збільшенням нормативної грошової оцінки земель сільськогосподарського призначення та зміною ставок цього податку. Але в чинному законодавстві не передбачено ставок єдиного податку для органічних землекористувачів, які зможуть стимулювати розвиток органічного виробництва на території України.

Як підкреслює Ю. Лупенко, податкове навантаження на сільгосппідприємства у рамках застосування спрощеної системи оподаткування, що введена в дію з 1.01.2015 р., не перевищує відповідних показників інших систем оподаткування - спрощеної (від доходу) та загальної (від прибутку). Таке навантаження, зважаючи на фрактичну доходність агробізнесу останніми роками, не повинно стати критичним для галузі [18]. Якби ставки земельних податкових платежів були вищими, то, на думку В. Голяна та В. Бардась, землекористувач максимально використовував би внутрішні резерви та зовнішні запозичення для впровадження інноваційних технологій, оскільки це може уможливити єдиний шлях закріплення на ринку та отримання конкурентних переваг [19].

Для стабільних надходжень до місцевих бюджетів та стимулювання ефективного використання земельних ресурсів необхідним $€$ вжиття низки заходів, серед яких: здійснення повної інвентаризації земель сільськогосподарського призначення, застосування підвищувальних коефіцієнтів за нераціональне використання земель сільськогосподарського призначення тощо.

Висновки. Загалом, ситуація у сорері користування землями сільськогосподарського призначення, їх охорони, ринку купівлі-продажу та запровадження системи відповідних платежів є складною та потребує заходів 3 трансформації платежів за їх користування.

За результатами дослідження плату за землю було визначено другим за обсягом джерелом фіскальних надходжень до місцевих бюджетів. Розкрито зміни у фрормуванні бюджетів місцевого самоврядування, серед яких зменшення частки плати за землю у податкових доходах зведеного бюджету України за умови збереження динаміки зростання фрактичних надходжень. Обгрунтовано значення єдиного податку четвертої групи як податкового регулятора використання земель сіль- 
ськогосподарського призначення та джерела наповнення місцевих бюджетів.

Сплата єдиного податку органічними землекористувачами є економічно вигідною, адже у такому разі вони звільняються від сплати податку на прибуток, податку на майно (в частині земельного податку) та рентної плати за спеціальне використання води платниками. Органічні землекористувачі, які займаються тваринницькою діяльністю, отримають податкові послаблення, адже об’єктом оподаткуван- ня є площа сільськогосподарських угідь, яка не впливає на спеціалізацію цих підприємств. Виробники органічної рослинної продукції також отримають економічну вигоду, адже за наявності прибутків, вони, за умови сплати єдиного податку, звільняються від сплати податку на прибуток. Окрім того, слід надати можливість органічним землекористувачам сплачувати єдиний податок за нижчими ставками, порівняно зі звичайними сільськогосподарськими землекористувачами.

\section{СПИСОК ВИКОРИСТАНИХ ДЖЕРЕЛ}

1. Павліха Н.В., Хомюк Н.Л. Трансоромація системи платежів за користування землями сільськогосподарського призначення: монографія. Луцьк: Волинянин, 2017. 242 с.

2. Державна казначейська служба України: офіц. веб-сайт: україн. версія.URL: http://www.treasury. gov.ua (дата звернення: 17.03.2019).

3. Інформаційно-ресурсний центр ІРЦ «Реформування земельних відносин в Україні». Плата за землю в Україні за 1992-2007. URL: http://myland.org.ua/index.php?id=343\&lang=uk (дата звернення: 10.10.2017).

4. Про внесення змін до Податкового кодексу України та деяких законодавчих актів України щодо податкової реформи: Закон України від 28.12.2014. № 71-VIII. URL: http://zakon2.rada.gov.ua/laws/ show/71-19 (дата звернення: 05.02.2019).

5. Про запобігання фінансової катастрофи та створення умов для економічного зростання в Україні: Закон України від 27.03.2014. № 1166-VII (зі змінами та доповненнями). URL: https://zakon.rada. gov.ua/laws/show/1166-18 (дата звернення: 13.02.2019).

6. Про внесення змін до Податкового кодексу України щодо покращення інвестиційного клімату в Україні: Закон України від 21.12.2016. № 1797-VIII URL: https://zakon.rada.gov.ua/laws/show/179719 (дата звернення: 13.02.2019).

7. Про схвалення Концепції реформування місцевого самоврядування та територіальної організації влади в Україні: Розпорядження Кабінету Міністрів України від 01.04.2014. № 333-p. URL: http:// zakon2.rada.gov.ua/laws/show/333-2014-\%D1\%80 (дата звернення: 10.10.2017).

8. Хомюк Н.Л. Децентралізація як чинник диверсифікації розвитку сільських територій // Економічний часопис Східноєвропейського національного університету імені Лесі Українки. 2019. № 1 (17). C. $85-91$.

9. Голян В. Залишатися на місцях: як і чим наповнити бюджети громад. URL: https://mind.ua/ openmind/20179359-zalishatisya-na-miscyah-yak-i-chim-napovniti-byudzheti-gromad (дата звернення: 10.01.2019).

10. Податковий кодекс України: прийнятий Верховною Радою України 2 груд. 2010 р. № 2755-IV: текст із змін. станом на 23 серп. 2018 р. URL: http://zakon4.rada.gov.ua/laws/show/2755-17 (дата звернення: 13.02.2019).

11. Державна служба України з питань геодезії, картографії та кадастру: офіц. веб-сайт: україн. версія. URL: http://land.gov.ua (дата звернення: 10.03.2019).

12. Хомюк Н.Л. Розвиток оренди земель сільськогосподарського призначення в умовах глобалізації // International Scientific-Practical Conference Modern Transformation of Economics and Management in the Era of Globalization: Conference Proceedings. January 29, 2016. Klaipeda: Baltija Publishing. P. 230-233.

13. Вартість сільськогосподарських земель та ї оренди у країнах Європейського Союзу та Україні. URL: http://zemvisnuk.com.ua/page/vart-st-zemel-ta-kh-orendi (дата звернення: 12.03.2019).

14. Дем'янчук О.І. Фіскальний потенціал місцевих бюджетів України // Науковий вісник Національного університету ДПС України (економіка, право). 2011. № 4 (55) С. 121-128.

15. Ступень М., Дудич Л. Особливості використання земель сільськогосподарського призначення в ринкових умовах // Економіст. 2011. № 4. С. 49-52.

16. Бондаренко B.M. Підвищення якості земель сільськогосподарського призначення // Екологічне оподаткування: збірник наукових праць за результати науково-практичних заходів (НДІ фрінансового права). К.: Алерта, 2013. С. 13-15.

17. Крисак А.І. Організаційно-економічні засади інституціонального забезпечення сільськогосподарського землекористування: автореф. дис. ... канд. ек. наук: 08.00 .06 / Рада по вивченню продуктивних сил України НАН України. Київ, 2009. 23 с. 
18. Лупенко Ю. Епоха фріксованого сільськогосподарського податку скінчилася. В дію вступають нові правила. URL: http://www.iae.org.ua/presscentre/archnews/1093-2015-01-13-12-47-50.html (дата звернення: 15.02.2019).

19. Голян В.А., Бардась В.М. Удосконалення системи фіскального регулювання природокористування: домінанти подолання синдрому «символічності» нормативів плати / Ф Формування ринкових відносин в Україні. 2011. № 11. С. 145-151.

\section{Інформація про автора}

Хомюк Наталія Леонідівна — кандидат економічних наук, докторант кафедри міжнародних економічних відносин та управління проектами, Східноєвропейський національний університет імені Лесі Українки (Україна, 43025, м. Луцьк, просп. Волі, 13, e-mail: nataljabilous@gmail.com).

N.L. Khomiuk

$\mathrm{PhD}$ in Economics

Lesya Ukrainka Eastern European National University (Ukraine, Lutsk, e-mail: nataljabilous@gmail.com)

\section{DYNAMICS OF SETTLEMENT AND RECEIPT OF LAND PAYMENTS IN TRADITIONAL AND ORGANIC AGRICULTURAL LAND USE IN UKRAINE}

The article analyzes the settlement and receipt of land payments in traditional and organic agricultural land use in Ukraine. A decrease in the share of land payment in the tax revenues of the consolidated budget of Ukraine was found, provided that the dynamics of the growth of actual revenues were maintained. The changes in the structure of the payment for land in the direction of increasing the share of rent in this structure are revealed. The analysis of the receipt of land payment to local budgets in the context of taxpayers is carried out. It was found that the receipt of this payment from legal entities is about $90 \%$, while from individuals - about 10\%. The analysis of the structure of land revenues in dynamics for the period of 2012 - 2018 using the balance sheet method has allowed revealing the influence of each element of the payment for land on the total amount of revenues and the dynamics of changes in their revenues over the years. The significance of the unified tax of the fourth group as a tax regulator for the use of agricultural land and sources of local budgets is substantiated. It was found that the income from the single tax payment for 2009-2014 has not changed, and in 2015 it increased by 17 times, as compared to the previous period, which is explained by the introduction of the annual indexation of the tax base and the increase of tax rates for agricultural enterprises. The only legitimate type of use of agricultural land is determined by lease. The tendency to increase is revealed. It is proposed to amend the tax legislation on payment of land payments by organic land users.

Keywords: land payment, payment for land, land tax, rent for land of state and communal property, land rent, single tax, local budget, agricultural land use, organic land use, legal entity, individual.

\section{REFERENCES}

1. Pavlikha, N.V. \& Khomiuk, N.L. (2017). Transformatsiia systemy platezhiv za korystuvannia zemliamy silskohospodarskoho pryznachennia [The transformation of payment system for use of agricultural land]. Lutsk: Volynianyn. 242 p. (In Ukr.)

2. The official site of the State Treasury Service of Ukraine. [Electronic source]. URL: http://www.treasury.gov.ua (In Ukr.)

3. Informatsiino-resursnyi tsentr IRTs «Reformuvannia zemelnykh vidnosyn v Ukraini». Plata za zemliu v Ukraini za 1992-2007. [The Information Resource Center of IRC «Land Relations Reform in Ukraine». Payment for Land in 1992-2007]. [Electronic source]. URL: http://myland.org.ua/index. php?id=343\&lang=uk (In Ukr.)

4. The Verkhovna Rada of Ukraine (2014), The Law of Ukraine «On Amendments to the Tax Code of Ukraine and Certain Legislative Acts of Ukraine on Tax Reform». Retrieved from: http://zakon2.rada. gov.ua/laws/show/71-19 (date of accesse: 05.02.2019)

5. The Verkhovna Rada of Ukraine (2014), The Law of Ukraine «On Prevention of Financial Crisis and Creation of Conditions for Economic Growth in Ukraine». Retrieved from: https://zakon.rada.gov. ua/laws/show/1166-18 (date of accesse: 13.02.2019)

6. The Verkhovna Rada of Ukraine (2016), The Law of Ukraine «On Amendments to the Tax Code of Ukraine on Improving the Investment Climate in Ukraine». Retrieved from: https://zakon.rada.gov. ua/laws/show/1797-19 (date of accesse: 13.02.2019) 
7. Cabinet of Ministers of Ukraine (2014), Order «On Approving the Concept of Reforming Local SelfGovernment and Territorial Organization of Power in Ukraine». Retrieved from: http://zakon2.rada. gov.ua/laws/show/333-2014-\%D1\%80 (date of accesse: 10.10.2017)

8. Khomiuk, N.L. (2019). Detsentralizatsiia yak chynnyk dyversyfikatsii rozvytku silskykh terytorii [Decentralization as a factor of diversification of development of rural territories]. Ekonomichnyi chasopys Skhidnoievropeiskoho natsionalnoho universytetu imeni Lesi Ukrainky [Economic journal of Lesia Ukrainka Eastern European National University], 1 (17). 85-91. (In Ukr.)

9. Holian, V. (2017). Zalyshatysia na mistsiakh: yak i chym napovnyty biudzhety hromad [To stay on the ground: how and what to fill the budgets of the communities]. [Electronic source]. URL: https://mind. ua/openmind/20179359-zalishatisya-na-miscyah-yak-i-chim-napovniti-byudzheti-gromad (in Ukr.)

10. The Verkhovna Rada of Ukraine (2016), The Tax Code of Ukraine. Retrieved from: http://zakon4.rada. gov.ua/laws/show/2755-17 (date of accesse: 13.02.2019)

11. The official site of the State Service of Ukraine for Geodesy, Cartography and Cadastre. [Electronic source]. URL: http://land.gov.ua (in Ukr.)

12. Khomiuk, N.L. (2016). "Rozvytok orendy zemel silskohospodarskoho pryznachennia $v$ umovakh hlobalizatsii» Proceedings of the International Scientific and Practical Conference [Modern Transformation of Economics and Management in the Era of Globalization]. International Scientific-Practical Conference. Baltija Publishing. Klaipeda, Lithuania. pp. 230-233. (In Ukr.)

13. Vartist silskohospodarskykh zemel ta yikh orendy u krainakh Yevropeiskoho Soiuzu ta Ukraini [The cost of agricultural land and its lease in the countries of the European Union and Ukraine]. [Electronic source]. URL: http://zemvisnuk.com.ua/page/vart-st-zemel-ta-kh-orendi (in Ukr.)

14. Demianchuk, O.I. (2011). Fiskalnyi potentsial mistsevykh biudzhetiv Ukrainy [Fiscal Capacity of Local Budgets of Ukraine]. Naukovyi visnyk Natsionalnoho universytetu DPS Ukrainy (ekonomika, pravo) [Scientific Bulletin of the National University of the State Tax Service of Ukraine (Economics, Law)]. 4 (55), 121-128. (In Ukr.)

15. Stupen, M. \& Dudich, L. (2011). Osoblyvosti vykorystannia zemel silskohospodarskoho pryznachennia v rynkovykh umovakh [Features of agricultural land use in market conditions]. Ekonomist [Economist], 4. 49-52. (In Ukr.)

16. Bondarenko, V.M. (2013). Pidvyshchennia yakosti zemel silskohospodarskoho pryznachennia [Improving the quality of agricultural land]. Ekolohichne opodatkuvannia: zbirnyk naukovykh prats za rezultaty naukovo-praktychnykh zakhodiv (NDI finansovoho prava) [Ecological taxation: a collection of scientific works on the results of scientific and practical events (Research Institute of Financial Law)]. K.: Alerta. 13-15. (in Ukr.)

17. Krysak, A.I. (2009). Orhanizatsiino-ekonomichni zasady instytutsionalnoho zabezpechennia silskohospodarskoho zemlekorystuvannia [Organizational-economic principles of institutional provision of agricultural land use]: author's abstract. dis. ... econom. sciences: 08.00.06 / Council for the Study of Productive Forces of Ukraine NAS of Ukraine. Kyiv, 2009. 23. (in Ukr.)

18. Lupenko, Yu. (2015). Epokha fiksovanoho silskohospodarskoho podatku skinchylasia. V diiu vstupaiut novi pravyla. [The era of a fixed agricultural tax is over. The new rules come into force]. [Electronic source]. URL: http://www.iae.org.ua/presscentre/archnews/1093-2015-01-13-12-47-50.html (In Ukr.)

19. Holian, V.A. \& Bardas, V.M. (2011). Udoskonalennia systemy fiskalnoho rehuliuvannia pryrodokorystuvannia: dominanty podolannia syndromu «symvolichnosti» normatyviv platy [Improvement of the system of fiscal regulation of nature use: the dominant overcoming the syndrome of «symbolism» of payment standards]. Formuvannia rynkovykh vidnosyn $v$ Ukraini [Formation of market relations in Ukraine], 11, 145-151. (In Ukr.)

\section{Author}

Khomiuk Nataliia Leonidivna - PhD in Economics, Doctoral Student of the Department of International Economic Relations and Project Management, Lesya Ukrainka Eastern European National University (Ukraine, 43025, Lutsk, 13 Volya Avenue, e-mail: nataljabilous@gmail.com). 